\title{
ANALISIS PERUBAHAN PENGGUNAAN LAHAN MENJADI LAHAN TERBANGUN PASCA PERPINDAHAN IBUKOTA KABUPATEN SUKABUMI DI WILAYAH TELUK PALABUHANRATU
}

\author{
Analysis of Land Use Change into Built-up Area on Post-Relocation \\ of Sukabumi Regency Capital in Palabuhanratu Bay Area
}

Yuda Pringgo Bayusukmaraํㅜ, Baba Barus ${ }^{2}$ and Akhmad Fauzi ${ }^{3}$

Diterima: 12 Februari 2018

Disetujui: 17 Agustus 2018

\begin{abstract}
Abstrak: Pemindahan Ibukota Kabupaten Sukabumi dari Kota Sukabumi ke Kecamatan Palabuhanratu dilakukan dalam rangka pemerataan pembangunan dan keseimbangan wilayah. Hal ini tentunya berimplikasi pada orientasi kebijakan pembangunan di wilayah Teluk Palabuhanratu, sehingga terjadi perubahan penggunaan lahan terutama perubahan menjadi lahan terbangun. Penelitian ini bertujuan untuk menganalisis perubahan penggunaan lahan periode pra perpindahan dan pasca perpindahan ibukota kabupaten, melakukan prediksi perubahan penggunaan lahan, menentukan variabel-variabel kunci serta pengaruhnya terhadap perubahan penggunaan lahan menjadi lahan terbangun, dan merumuskan arahan pengendalian pemanfaatan ruang lahan terbangun di wilayah Teluk Palabuhanratu. Penelitan ini diawali dengan menganalisis perubahan penggunaan lahan dengan teknik overlay. Prediksi perubahan penggunaan lahan dilakukan dengan metode Markov Chain dan CA-Markov Chain. Prospective Structural Analysis (PSA) dengan metode MICMAC digunakan untuk menentukan variabel-variabel kunci yang berpengaruh terhadap perubahan penggunaan lahan menjadi lahan terbangun. Hasil penelitian menunjukkan pada periode pasca perpindahan ibukota, perubahan penggunaan lahan menjadi lahan terbangun mengalami peningkatan kenaikan luasan dibanding dengan periode sebelumnya. Hasil prediksi tahun 2030 menunjukkan penggunaan lahan pasir pantai mengalami penurunan luasan terbesar dibanding luas lahan sebelumnya, sementara lahan terbangun mengalami kenaikan terbesar. Variabel-variabel kunci yang berpengaruh terhadap perubahan penggunaan lahan menjadi lahan terbangun pada kondisi saat ini adalah jarak terhadap pusat kota, kebijakan RTRW, dan kelerengan. Pada kondisi yang akan datang, jarak terhadap kota, kebijakan RTRW, dan proporsi luas lahan sawah diprediksi akan menjadi variabel-variabel kunci yang berpengaruh terhadap perubahan penggunaan lahan menjadi lahan terbangun.
\end{abstract}

Kata kunci: perpindahan ibukota, perubahan penggunaan lahan, lahan terbangun, cellular automata, prospective structural analysis.

Abstract: The removal of Sukabumi Regency Capital from Sukabumi Municipality to Palabuhanratu District was done in order to equalize the region equitable development. It had implicated to orientation of development policies in Palabuhanratu Bay area, so that caused the land use change especially from

\footnotetext{
${ }^{1}$ Program Studi Ilmu Perencanaan Wilayah, Sekolah Pascasarjana, Institut Pertanian Bogor

${ }^{2}$ Departemen Ilmu Tanah dan Sumberdaya Lahan, Fakultas Pertanian, Institut Pertanian Bogor

${ }^{3}$ Departemen Ekonomi Sumberdaya alam dan Lingkungan, Fakultas Ekonomi dan Manajemen Institut Pertanian Bogor
} 
non built-up area into built-up area. The objectives of this research were: 1) to analyze land use change in pre-relocation and post-relocation period of regency capital; 2) to analyze predictions of land use change; 3) determining the key variables and their influence on the land use change into built-up area; and 4) to arrange the guidance of controlling the utilization of built-up area in the Palabuhanratu Bay area. This research was begun by analyzing land use change using overlay tecnique. Markov Chain and CA-Markov Chain method were used to predict land use change. Prospective Structural Analysis using MICMAC method was used to determine key variables in influencing the land use change into built-up area. The results showed that in the period of post-relocation, the built-up area had a significant increase than the period of pre-relocation. The prediction results of 2030 indicate the type of land use which had a significant decrease was beach sand, while the built-up area will be increasing. The key variables that influenced the land use change into built-up area in the present situation were distance to the city center, Regional Spatial Plan policy, and slope. In future situation, variables such as distance to cities, Regional Spatial Plan policy, and the proportion of paddy field will be the key variables in influencing the land use change into built-up area.

Keywords: regency capital relocation, land use change, built-up area, cellular automata, prospective structural analysis.

\section{PENDAHULUAN}

Dalam rangka pemerataan pembangunan dan keseimbangan wilayah, salah satu upaya yang dilakukan oleh Pemerintah Kabupaten Sukabumi adalah dengan melakukan pemindahan ibukota Kabupaten dari Kota Sukabumi yang berada di bagian Utara ke Kecamatan Palabuhanratu di bagian Selatan Kabupaten Sukabumi berdasarkan Peraturan Pemerintah Nomor 66 Tahun 1998 pada tahun 2002. Dampak dari perpindahan ibukota kabupaten tersebut salah satunya berimplikasi terhadap orientasi kebijakan pengembangan wilayah yang tercermin dari kebijakan tata ruang wilayah khususnya di perkotaan Palabuhanratu dan kecamatan yang berbatasan langsung, sehingga memicu terjadinya perubahan penggunaan lahan. Adapun kecamatan pesisir yang secara administrasi berbatasan dengan Teluk Palabuhanratu terdiri dari empat kecamatan, yaitu Cisolok, Cikakak, Palabuhanratu dan Simpenan (PKSPL-IPB, 2003c dalam Wahyudin, 2011).

Berdasarkan penelitian Muiz (2009), pada tahun 2000-2006 terjadi peningkatan hirarki Kecamatan Palabuhanratu dari hirarki 2 ke hirarki 1. Hal ini menunjukkan bahwa Kecamatan Palabuhanratu berfungsi sebagai pusat pelayanan terhadap wilayah di sekitarnya sebagai hinterland. Perpindahan ibukota kabupaten juga berimplikasi kepada pertambahan jumlah penduduk. Hal ini berpengaruh terhadap peningkatan kebutuhan tempat tinggal dan fasilitas penunjangnya, pada akhirnya memengaruhi pengurangan jumlah luas ketegori penggunaan lahan lainnya (Hidayat et al. 2015).

Rencana Tata Ruang Wilayah (RTRW) Propinsi Jawa Barat Tahun 2009-2029 yang ditindaklanjuti oleh RTRW Kabupaten Sukabumi tahun 2012-2032, menetapkan kawasan perkotaan Palabuhanratu sebagai kawasan pengembangan pusat kegiatan permukiman, bisnis kelautan, potensi perikanan, dan pariwisata. Di sisi lain, juga ditetapkan kawasan strategis dari sudut kepentingan fungsi dan daya dukung lingkungan hidup. Dengan demikian, pengembangan kawasan dengan sudut kepentingan yang berbeda berpotensi terjadi perubahan penggunaan lahan yang tinggi di kawasan dengan fungsi lindung.

Tujuan penelitian ini antara lain: 1) menganalisis perubahan penggunaan lahan periode pra perpindahan dan pasca perpindahan ibukota kabupaten; 2) melakukan prediksi perubahan penggunaan lahan; 3) menentukan variabel-variabel kunci serta pengaruhnya terhadap perubahan penggunaan lahan menjadi lahan terbangun; 4) merumuskan arahan pengendalian pemanfaatan ruang lahan terbangun di wilayah Teluk Palabuhanratu. 


\section{METODE}

\section{Lokasi dan Waktu Penelitian}

Penelitian ini dilakukan di wilayah Teluk Palabuhanratu Kabupaten Sukabumi yang terdiri dari 4 kecamatan, yaitu Kecamatan Cisolok, Cikakak, Palabuhanratu, dan Simpenan dengan luas wilayah keseluruhan 56.641,27 Ha.

\section{Jenis dan Sumber Data}

Alat yang digunakan terdiri seperangkat komputer, Global Positioning System (GPS), dan kamera digital. Perangkat lunak (software) yang digunakan dalam mengolah data antara lain ArcGIS 10, Microsoft Office, Idrisi Selva, dan MICMAC (Matrice d'Impact Croisés-Multiplication Appliquée a un Classement). Data yang digunakan meliputi peta administrasi dan peta kelerengan (RTRW Kabupaten Sukabumi 2012-2032), citra satelit meliputi citra Landsat 4-5 TM (tahun 1988), Landsat 7 ETM+ SLC-on (tahun 2002), dan Landsat 8 OLI/TIRS (Tahun 2016). Data mengenai variabel-variabel yang memengaruhi perubahan penggunaan lahan didapat dari studi berbagai literatur.

\section{Analisis Data}

\section{Analisis Perubahan Penggunaan Lahan}

Karakteristik utama dari SIG adalah kemampuan untuk menganalisis sistem seperti analisis statistik dan overlay yang disebut analisis spasial (Handayani et al. 2005). Data penginderaan jauh berupa citra satelit merupakan salah satu data yang sering digunakan dalam aplikasi SIG (Wijaya, 2015). Cara mengkaji perubahan penggunaan lahan antara lain dengan menghitung luas perubahan, menghitung tingkat perubahan, menganalisis pola perubahan dan pemodelan (Susilo, 2011). Analisis perubahan penggunaan lahan dilakukan menggunakan Sistem Informasi Geografis (SIG) dengan metode tumpang susun (overlay) peta penggunaan lahan yang diperoleh dari interpretasi citra satelit Landsat tahun 1988, 2002, dan 2016. Peta dalam penelitian ini dibuat dalam skala 1:50.000. Hal ini berdasarkan resolusi spasial yang sepadan dengan citra Landsat TM sesuai aturan Tobler (1987). Setelah diperoleh peta penggunaan lahan pada masing-masing tahun, selanjutnya dilakukan deteksi dan analisis spasial perubahan penggunaan lahan yang meliputi dua periode waktu, yaitu periode praperpindahan ibukota kabupaten tahun 1988-2002 dan pascaperpindahan ibukota kabupaten tahun 2002-2016.

Bentuk produk suatu SIG dapat bervariasi baik dalam hal kualitas, keakuratan dan kemudahan pemakainya. Hasil ini dapat dibuat dalam bentuk peta-peta, tabel angka-angka, teks di atas kertas, atau dalam cetak lunak (Barus dan Wiradisastra, 2000). Deteksi perubahan penggunaan lahan menggunakan matriks transformasi dengan cara menumpangtindihkan peta penggunaan lahan periode pra perindahan ibukota kabupaten dengan periode pasca perpindahan ibukota kabupaten sehingga dihasilkan perubahan penutupan lahan ke perubahan lainnya termasuk luas dan sebarannya.

\section{Analisis Prediksi Perubahan Penggunaan lahan Tahun 2030}

Analisis prediksi perubahan penggunaan lahan dilakukan dengan tujuan untuk mengetahui bagaimana kemungkinan perubahan penggunaan lahan pada tahun 2030 pasca perpindahan ibukota kabupaten. Salah satu metode pemodelan yang banyak digunakan untuk memprediksi perubahan penggunaan lahan adalah CA-Markov (Wang, et al. 2012; Nouri, et al. 2014; Munibah 2008). Metode Markov adalah metode secara statistik dengan menggunakan matriks peluang peralihan berdasarkan berdasarkan efek kawasan pada 
algoritma yang memengaruhi ruang (Kim et al. 2011). Markov Chain dibangun dengan menggunakan distribusi penggunaan lahan pada awal dan akhir masa pengamatan (Trisasongko et al. 2009).

Data yang digunakan dalam analisis ini merupakan peta penggunaan lahan yang telah dikonversi menjadi data raster dan diolah menggunakan perangkat lunak IDRISI SELVA 17. Peta prediksi penggunaan lahan tahun 2030 dibangun berdasarkan matriks transisi penggunaan lahan 2002 dan 2016. Setelah itu kemudian dilakukan validasi model terhadap keakuratan hasil proyeksi. Validasi model dilakukan dengan membandingkan hasil simulasi tahun prediksi dengan peta penggunaan lahan aktual. Tingkat validitas data diharapkan nilainya tidak kurang dari 85\% (Jensen, 1996).

\section{Mengidentifikasi Variabel-variabel Kunci yang Memengaruhi Perubahan Penggunaan Lahan Menjadi Lahan Terbangun.}

Tahapan analisis ini menggunakan Prospective Structural Analysis (PSA) dengan metode MICMAC (Matrice d'Impact Croisés-Multiplication Appliquée a un Classement). Teknik PSA digunakan dengan asumsi bahwa kondisi yang akan terjadi pada masa depan tidak berdasarkan kecenderungan yang terjadi di masa lalu, tetapi bisa dibangun pada saat ini. Teknik ini dapat membantu menggambarkan sistem yang mengidentifikasi hubungan pengaruh di antara unsur-unsur (variabel) yang menyusunnya melalui proses diskusi kelompok (brainstorming). Jumlah daftar variabel sebaiknya tidak lebih dari 70-80 variabel dan masing-masing variabel harus didefinisikan dengan jelas (Serano et al. 2010).

Metode MICMAC dapat menentukan variabel-variabel kunci dari sebuah sistem berdasarkan pengaruh terbesar dari variabel-variabel tersebut dalam dua periode waktu (Albala et al. 2009), yaitu kondisi sampai dengan saat ini dan kondisi yang akan datang 1015 tahun kemudian dengan langkah-langkah berikut (Godet, 2008): 1) Mengidentifikasi variabel; 2) mendeskripsikan hubungan antarvariabel; 3) mengidentifikasi hubungan variabel; 4) menentukan variabel-variabel kunci yang memengaruhi perubahan penggunaan lahan menjadi lahan terbangun.

\section{Menganalisis Pengaruh Variabel-variabel Kunci Terhadap Perubahan Penggunaan Lahan Menjadi Lahan Terbangun}

Pada tahapan ini dilakukan analisis pengaruh variabel-variabel kunci hasil identifikasi pada tahapan analisis sebelumnya terhadap perubahan penggunaan lahan periode tahun 2002-2016 dan tahun 2016-2030. Metode yang digunakan dalam analisis ini adalah metode tumpang susun antara variabel-variabel kunci yang berpengaruh terhadap perubahan penggunaan lahan menjadi lahan terbangun dengan peta perubahan penggunaan lahan di wilayah Teluk Palabuhanratu.

\section{Arahan Pengendalian Pemanfaatan Ruang Lahan Terbangun}

Arahan pengendalian pemanfaatan ruang disusun secara deskriptif dengan mempertimbangkan rangkaian analisis yang telah dilakukan sebelumnya, yaitu analisis perubahan penggunaan lahan, prediksi perubahan penggunaan lahan, identifikasi variabelvariabel kunci serta pengaruhnya terhadap perubahan penggunaan lahan menjadi lahan terbangun di wilayah Teluk Palabuhanratu periode tahun 2002-2016 dan tahun 2016-2030. 


\section{HASIL DAN PEMBAHASAN}

\section{Analisis Perubahan Penggunaan Lahan}

Hasil interpretasi citra pada dasarnya merupakan penampakan dari penutupan lahan (Muiz, 2009). Kelas-kelas penggunaan lahan yang dihasilkan kemudian dilakukan verifikasi berdasarkan citra dari Google Earth dan cek lapangan (ground check). Hasil dari uji akurasi hasil interpretasi citra tahun 2016 adalah 87,80\% (very good agreement). Klasifikasi penggunaan lahan didasarkan pada kondisi fisik wilayah dan bentuk pemanfaatan sebagai ruang pembangunan (Setiawan dan Rudiarto, 2016). Klasifikasi penggunaan lahan ini menghasilkan 9 kelas yang mengacu pada klasifikasi yang ditetapkan BSN (2014) yang terdiri dari tubuh air, hutan, kebun campuran, ladang/tegalan, lahan terbangun, pasir pantai, perkebunan, sawah, dan semak/belukar.

Struktur penggunaan lahan di wilayah Teluk Palabuhanratu tahun 1988, 2002, maupun 2016 didominasi oleh jenis penggunaan lahan hutan dan sebagian besar berada di bagian utara, tengah, dan selatan. Besaran luas penggunaan lahan hutan di wilayah Teluk Palabuhanratu disebabkan terdapat hutan konservasi Taman Nasional Gunung HalimunSalak (TNGH-S) yang berada di Kecamatan Cisolok dan Cikakak, hutan lindung, hutan produksi, kawasan Cagar Alam dan Taman Wisata Alam Sukawayana (33 Ha), dan Cagar Alam Tangkubanparahu (22 Ha) yang berada di Kecamatan Palabuhanratu.
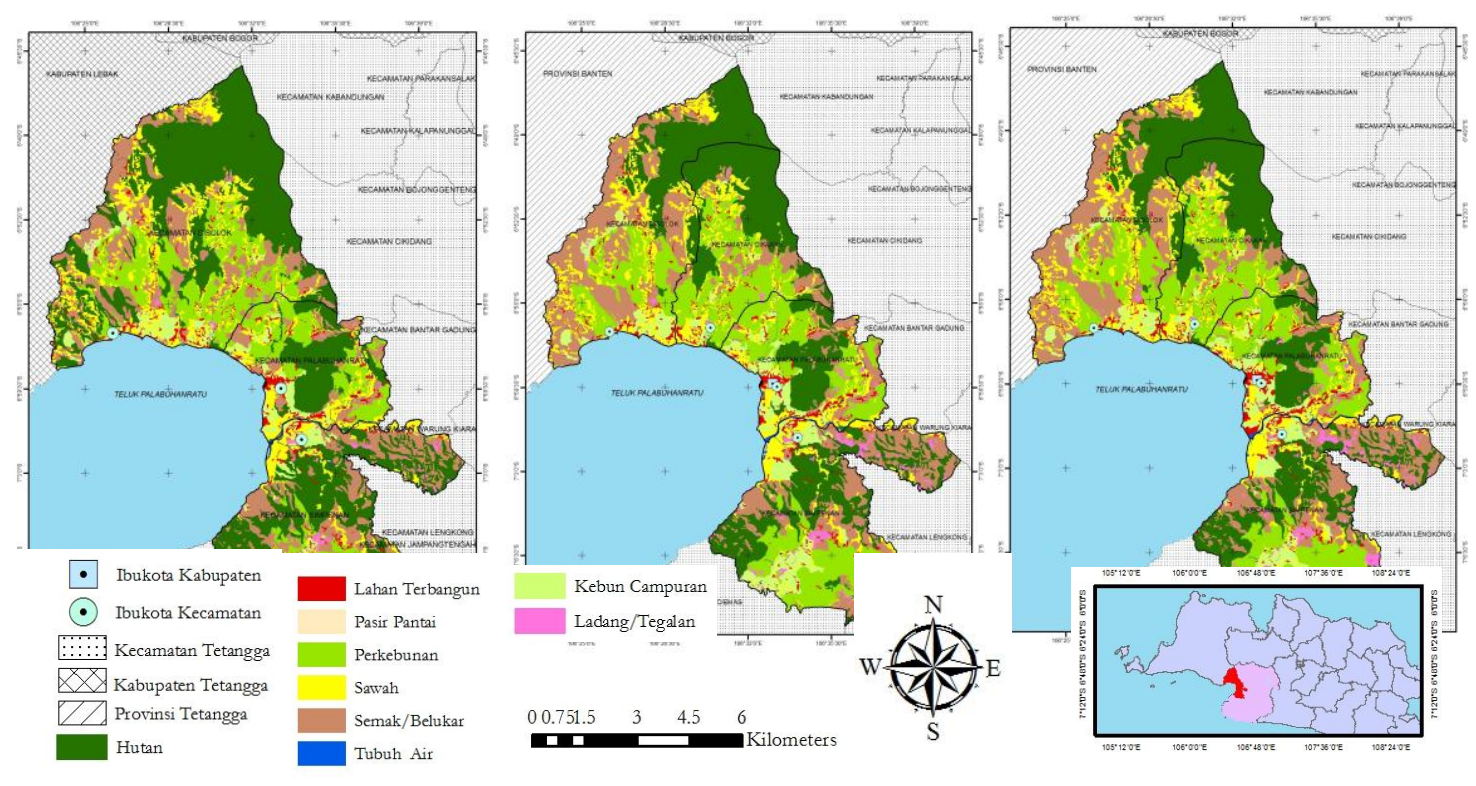

Gambar 1. Peta penggunaan lahan tahun 1988 kiri, 2002 (tengah), dan 2016 (kanan)

Penggunaan lahan yang mengalami kenaikan persentase luas terbesar dibanding luas lahan sebelumnya periode tahun 1988-2002 adalah lahan perkebunan (37,08\%) dan ladang/tegalan $(25,57 \%)$, sedangkan lahan hutan dan pasir pantai mengalami penurunan $(24,45 \%$ dan $24,38 \%$ ). Pada periode tahun 2002-2016, penggunaan lahan lahan terbangun dan ladang/tegalan mengalami kenaikan persentase luas terbesar (7,92\% dan 6,59\%), di sisi lain lahan pasir pantai dan tubuh air mengalami penurunan terbesar $(32,42 \%$ dan 2,96\%). Untuk lebih jelasnya disajikan pada Tabel 2 berikut. 
Tabel 1. Luas Penggunaan Lahan di Wilayah Teluk Palabuhanratu Tahun 1988, 2002, 2016, dan Perubahannya

\begin{tabular}{|c|c|c|c|c|c|c|c|}
\hline \multirow{2}{*}{$\begin{array}{l}\text { Penggunaan } \\
\text { Lahan }\end{array}$} & $\begin{array}{r}\text { Tahun } \\
1988\end{array}$ & $\begin{array}{l}\text { Tahun } \\
2002\end{array}$ & $\begin{array}{r}\text { Tahun } \\
2016\end{array}$ & \multicolumn{2}{|l|}{ Tahun 2016} & \multicolumn{2}{|c|}{ Perubahan 2002-2016 } \\
\hline & $(\mathrm{Ha})$ & (Ha) & (Ha) & (Ha) & $(\%)$ & (Ha) & $(\%)$ \\
\hline Hutan & $21.442,62$ & $16.199,81$ & $15.730,46$ & $-5.242,81$ & $-24,45$ & $-469,35$ & $-2,90$ \\
\hline $\begin{array}{l}\text { Kebun } \\
\text { Campuran }\end{array}$ & $3.085,74$ & $3.663,08$ & $3.631,81$ & 577,34 & 18,71 & $-31,27$ & $-0,85$ \\
\hline Ladang/Tegalan & 674,77 & 847,28 & 903,10 & 172,51 & 25,57 & 55,82 & 6,59 \\
\hline $\begin{array}{l}\text { Lahan } \\
\text { Terbangun }\end{array}$ & $1.651,46$ & $1.753,05$ & $1.891,87$ & 101,59 & 6,15 & 138,82 & 7,92 \\
\hline Pasir Pantai & 58,53 & 44,26 & 29,91 & $-14,27$ & $-24,38$ & $-14,35$ & $\begin{array}{l}- \\
32.42\end{array}$ \\
\hline Perkebunan & $8.991,88$ & $12.325,66$ & $12.458,28$ & $3.333,78$ & 37,08 & 132,62 & 1,08 \\
\hline Sawah & $6.814,93$ & $7.050,63$ & $7.011,66$ & 235,70 & 3,46 & $-38,97$ & $-0,55$ \\
\hline Semak/Belukar & $11.616,74$ & $12.470,94$ & $12.706,11$ & 854,20 & 7,35 & 235,17 & 1,89 \\
\hline Tubuh Air & 304,60 & 286,56 & 278,07 & $-18,04$ & $-5,92$ & $-8,48$ & $-2,96$ \\
\hline Jumlah & $54.641,27$ & $54.641,27$ & $54.641,27$ & & & & \\
\hline
\end{tabular}

Dinamika konversi penggunaan lahan serta arah perubahannya diperoleh dari hasil klasifikasi silang (cross classification) dengan membandingkan atribut penggunaan lahan antar titik tahun sehingga bisa diketahui wilayah yang tetap dan wilayah yang mengalami perubahan (Trisasongko et al. 2009). Hasil klasifikasi silang menunjukkan pola perubahan penggunaan lahan pada periode tahun 1988-2002 terutama terjadi pada penggunaan lahan hutan-semak/belukar dan semak/belukar-perkebunan. Pada periode tahun 2002-2016 pola perubahan lahan terutama terjadi pada penggunaan lahan hutan ke semak/belukar dan non terbangun ke lahan terbangun. Peta pola perubahan penggunaan lahan periode tahun 1988-2002 dan tahun 2002-2016 disajikan pada Gambar 2.

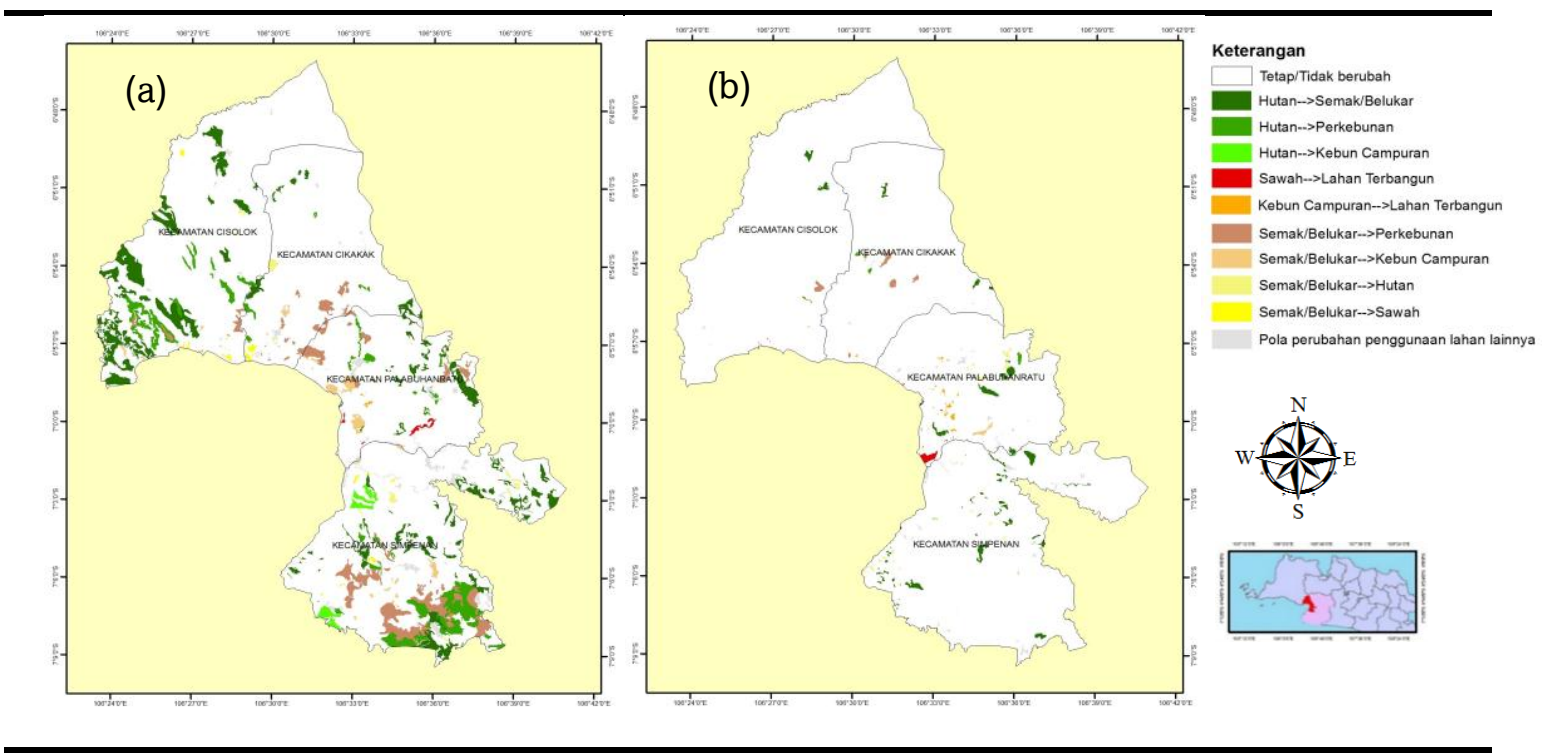

Gambar 2. Sebaran Perubahan Penggunaan Lahan Tahun 1988-2002 (a) dan Tahun 2002-2016 (b)

Perubahan penggunaan lahan pada dasarnya tidak dapat dihindari, sedangkan lahan itu sendiri bersifat terbatas (Septiono dan Mussadun, 2016). Kontribusi terbesar konversi menjadi lahan terbangun adalah pembangunan Pembangkit Listrik Tenaga Uap (PLTU) seluas $\pm 50 \mathrm{Ha}$ yang sebelumnya sebagian besar merupakan lahan sawah di Kecamatan Palabuhanratu. Penambahan luas lahan terbangun juga diperoleh dari penggunaan lahan 
kebun campuran akibat pembangunan prasarana dan sarana dalam mendukung kegiatan pemerintahan, perekonomian, dan kegiatan pariwisata. Penambahan luas penggunaan lahan terbangun di Kecamatan Cisolok, Cikakak dan Simpenan lebih disebabkan kedudukannya sebagai wilayah hinterland karena berbatasan langsung dengan Kecamatan Palabuhanratu sebagai pusat pelayanan pemerintahan dan ekonomi sehingga dalam pengembangannya dibangun sarana penunjang seperti hotel/penginapan dan restoran/rumah makan.

\section{Prediksi Perubahan Penggunaan Lahan Tahun 2030}

Simulasi perubahan penggunaan lahan dilakukan untuk memprediksi perubahan penggunaan lahan tahun 2030 berdasarkan kecenderungan perubahan penggunaan lahan tahun 2002-2016. Peta hasil prediksi tahun 2030 disajikan pada Gambar 3.

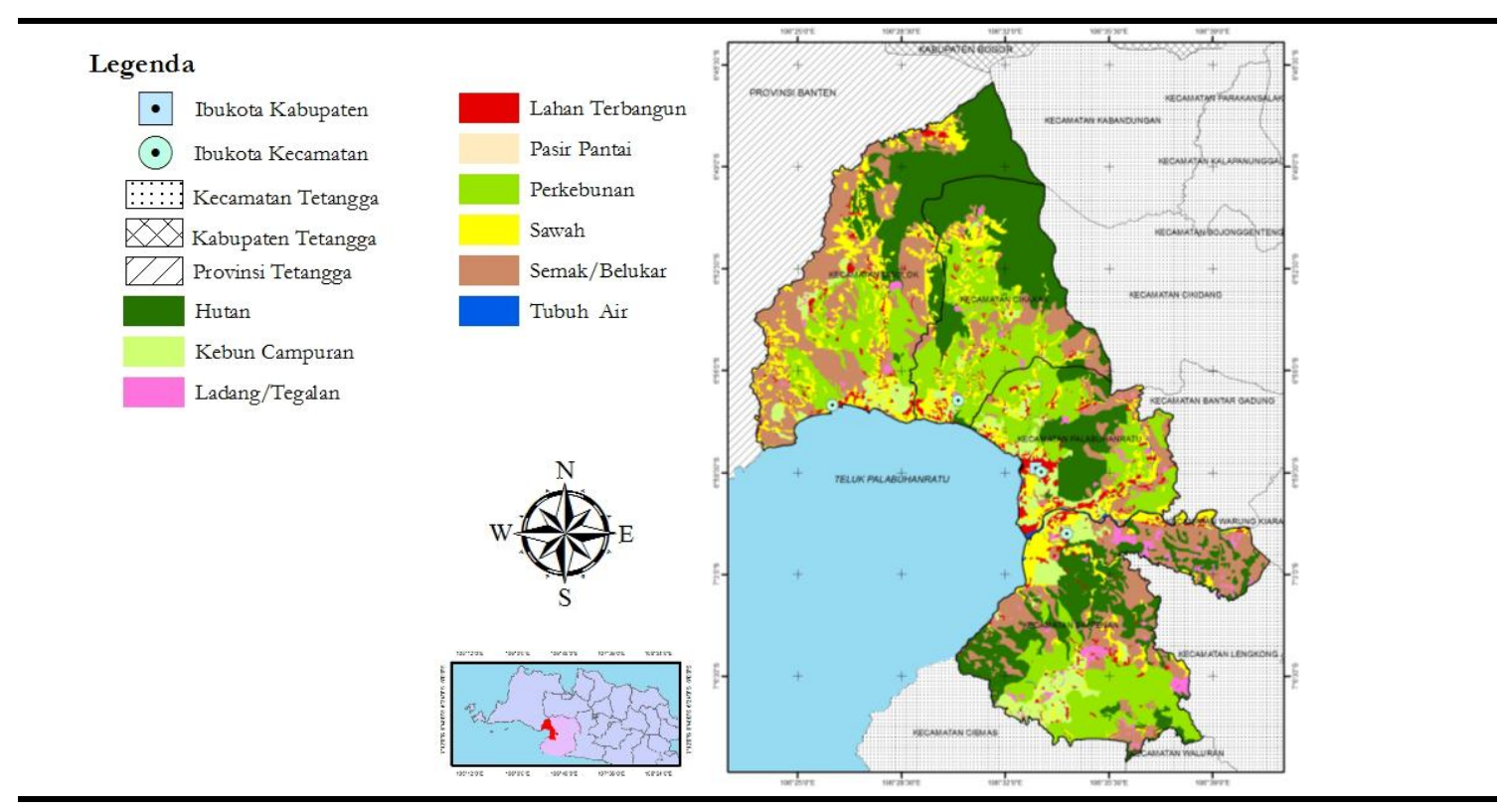

Gambar 3. Peta Prediksi Penggunaan Lahan Tahun 2030

Berdasarkan hasil simulasi prediksi perubahan penggunaan lahan, dihasilkan ketepatan hasil prediksi penggunaan lahan pada tahun 2016 dengan referensi penggunaan lahan tahun 2016 hasil interpretasi citra berupa nilai kappa sebesar 85,89\%. Nilai akurasi yang tinggi mengijinkan untuk dilakukan analisis selanjutnya, yaitu memprediksi penggunaan lahan tahun 2030 seperti tersaji pada Tabel 5.

Jenis penggunaan lahan yang diprediksi mengalami kenaikan luasan yang cukup signifikan dibanding luasan lahan sebelumnya dari tahun 2016-2030 di wilayah Teluk Palabuhanratu adalah lahan terbangun sebesar 12,19\% (230,68 Ha), semak/belukar 
Tabel 2. Luas Penggunaan Lahan di Wilayah Teluk Palabuhanratu

Tahun 2016-2030, dan Perubahannya

\begin{tabular}{|c|c|c|c|c|c|c|c|}
\hline \multirow[b]{2}{*}{ Penggunaan Lahan } & \multicolumn{2}{|l|}{ Tahun 2016} & \multicolumn{2}{|l|}{ Tahun 2030} & \multicolumn{3}{|c|}{ Perubahan 2016-2030 } \\
\hline & Luas (Ha) & $\%$ & Luas (Ha) & $\%$ & $\begin{array}{l}\text { Luas } \\
\text { (Ha) }\end{array}$ & $\begin{array}{l}\text { Selisih } \\
(\%)\end{array}$ & $\begin{array}{l}\text { Awal } \\
(\%)\end{array}$ \\
\hline Hutan & $15.730,46$ & 28,79 & $15.285,02$ & 27,97 & $-445,44$ & $-0,82$ & $-2,83$ \\
\hline Kebun Campuran & $3.631,81$ & 6,65 & $3.602,51$ & 6,59 & $-29,30$ & $-0,05$ & $-0,81$ \\
\hline Ladang/Tegalan & 903,10 & 1,65 & 916,94 & 1,68 & 13,85 & 0,03 & 1,53 \\
\hline Lahan Terbangun & $1.891,87$ & 3,46 & $2.122,55$ & 3,88 & 230,68 & 0,42 & 12,19 \\
\hline Pasir Pantai & 29,91 & 0,05 & 21,66 & 0,04 & $-8,26$ & $-0,02$ & 2760 \\
\hline Perkebunan & $12.458,28$ & 22,80 & $12.619,23$ & 23,09 & 160,95 & 0,29 & 1,29 \\
\hline Sawah & $7.011,66$ & 12,83 & $6.903,09$ & 12,63 & $-108,58$ & $-0,20$ & $-1,55$ \\
\hline Semak/Belukar & $12.706,11$ & 23,25 & $12.914,92$ & 23,64 & 208,81 & 0,38 & 1,64 \\
\hline Tubuh Air & 278,07 & 0,51 & 252,41 & 0,46 & $-25, \epsilon$ & $-0,05$ & $-9,23$ \\
\hline Jumlah & $54.641,27$ & 100,00 & $54.638,33$ & 100,00 & & & \\
\hline
\end{tabular}

$1,64 \%$ (208,81 Ha) dan ladang/tegalan 1,53\% (13,85 Ha). Sementara itu, penggunaan lahan yang diprediksi mengalami penurunan terbesar pada tahun 2030 adalah pasir pantai sebesar 27,60\% (8,26 Ha), tubuh air 9,23\% (25,66 Ha), dan hutan 2,83\% (445,44 Ha). Kenaikan luas lahan terbangun akan selalu diikuti oleh penurunan lahan sawah dan kebun campuran, sedangkan kenaikan luas semak/belukar akan selalu diikuti oleh penurunan lahan hutan.

\section{Variabel-variabel Kunci yang Memengaruhi Perubahan Penggunaan Lahan menjadi Lahan Terbangun}

Penentuan variabel-variabel kunci yang memengaruhi proses perubahan penggunaan lahan menjadi lahan terbangun di wilayah Teluk Palabuhanratu dilakukan melalui Prospective Structural Analysis (PSA) dengan menerapkan metode MICMAC dengan langkah-langkah berikut:

Penentuan variabel-variabel kunci diawali dengan mengidentifikasi variabel-variabel yang dianggap penting dalam proses perubahan penggunaan lahan menjadi lahan terbangun di wilayah Teluk Palabuhanratu. Studi literatur menghasilkan 24 variabel yang mengerucut menjadi 15 variabel setelah dilakukan proses diskusi (Tabel 3).

Tabel 3. Daftar Variabel Hasil Konsensus

\begin{tabular}{llll}
\hline No. & Variabel No. & Variabel \\
\hline 1 & Kepadatan penduduk & 9 & $\begin{array}{l}\text { Iklim } \\
\text { Proporsi luas lahan } \\
\text { sawah }\end{array}$ \\
3 & $\begin{array}{l}\text { Kebutuhan lahan } \\
\text { perumahan/permukiman } \\
\text { Kelengkapan prasarana dan } \\
\text { sarana }\end{array}$ & 10 & Tingkat pendidikan \\
4 & Kebijakan RTRW & 12 & Pariwisata \\
5 & $\begin{array}{l}\text { Pertumbuhan ekonomi } \\
\text { Jarak terhadap pusat kota }\end{array}$ & 13 & $\begin{array}{l}\text { Pendapatan } \\
\text { perkapita penduduk } \\
\text { Perijinan }\end{array}$ \\
\hline
\end{tabular}

Dalam tahap ini belum diketahui varibel yang paling menentukan dalam perubahan penggunaan lahan menjadi lahan terbangun di wilayah Teluk Palabuhanratu. Pengaruh antarvariabel juga belum dapat digambarkan, sehingga semua variabel memiliki kepentingan dan kekuatan yang sama terhadap sistem. 
Tabel 4. Cross-Impact Matrix

\begin{tabular}{|c|c|c|c|c|c|c|c|c|c|c|c|c|c|c|c|c|}
\hline & & $\begin{array}{l}\text { Kep } \\
\text { Pddk }\end{array}$ & $\begin{array}{l}\mathrm{Rp}_{-} \\
\mathrm{lhn}\end{array}$ & $\begin{array}{l}\begin{array}{l}\mathrm{Lhn}_{-} \\
\text {rmh }\end{array} \\
\end{array}$ & $\begin{array}{l}\text { Sar } \\
\text { pras }\end{array}$ & RTRW & PDRB & $\begin{array}{l}J_{\text {rk }} \\
\text { kota }\end{array}$ & $\begin{array}{l}\text { In } \\
\text { vest }\end{array}$ & Suhu & $\begin{array}{l}\text { Luas_ } \\
\text { Swh }\end{array}$ & Pddkn & Wisataw & perkapita & lereng & $\begin{array}{l}\text { Jns- } \\
\text { tnh }\end{array}$ \\
\hline 2 & Rp_lhn & 0 & 0 & 1 & 1 & 2 & 3 & 0 & 2 & 0 & 3 & 0 & 0 & 2 & 0 & 0 \\
\hline 3 & Lhn_rmh & 1 & 3 & 0 & 3 & 1 & 3 & 1 & 3 & 0 & 3 & 0 & 0 & 0 & 1 & 0 \\
\hline 5 & RTRW & 2 & $\mathrm{P}$ & 2 & 2 & 0 & $\mathrm{P}$ & 2 & 3 & 0 & 3 & 0 & $\mathrm{P}$ & 1 & 3 & 3 \\
\hline 6 & PDRB & 2 & 3 & 1 & 1 & 1 & 0 & 0 & 1 & 0 & 3 & 3 & 2 & 3 & 0 & 0 \\
\hline 7 & Jrk_kota & 3 & 3 & 3 & 3 & 2 & 3 & 0 & 2 & $\mathrm{P}$ & 3 & 3 & 0 & 3 & 0 & 0 \\
\hline 10 & Luas_swh & 0 & 3 & 3 & 0 & 3 & 3 & 1 & 1 & 0 & 0 & 1 & 0 & 3 & 2 & 0 \\
\hline 11 & Pddkn & 2 & 1 & 1 & 1 & 0 & 2 & 1 & 1 & 0 & 3 & 0 & 1 & 3 & 0 & 0 \\
\hline 12 & Wisatw & $\mathrm{P}$ & $\mathrm{P}$ & 1 & 3 & 1 & 3 & 0 & 3 & 0 & $\mathrm{P}$ & 2 & 0 & 3 & 0 & 0 \\
\hline 13 & Perkapita & 2 & $\mathrm{P}$ & 3 & 1 & 0 & 3 & 1 & 2 & 0 & 3 & 3 & 0 & 0 & 0 & 0 \\
\hline 14 & Lereng & 2 & 3 & 3 & 1 & 1 & 2 & 1 & 3 & 2 & 3 & 0 & 0 & 0 & 0 & 0 \\
\hline 15 & Jns_tnh & 0 & 2 & 0 & 0 & 2 & $\mathrm{P}$ & 0 & $\mathrm{P}$ & 0 & 3 & 0 & 0 & $\mathrm{P}$ & 0 & 0 \\
\hline
\end{tabular}

Keterangan:

Skor

0 = tidak ada pengaruh (no influence),

$1=$ pengaruh lemah (weak influence),

$2=$ pengaruh sedang (medium influence)

$3=$ pengaruh kuat, dan (strong influence),

$\mathrm{P}=$ pengaruh potensial (potential influence)

Langkah selanjutnya adalah mendeskripsikan hubungan antarvariabel dengan cara pemberian skor pada Cross-Impact Matrix berukuran 15x15 dengan mempertimbangkan pengaruh dari masing-masing variabel yang telah didiskusikan dan disepakati oleh peserta dalam kelompok diskusi seperti yang tersaji pada Tabel 4.

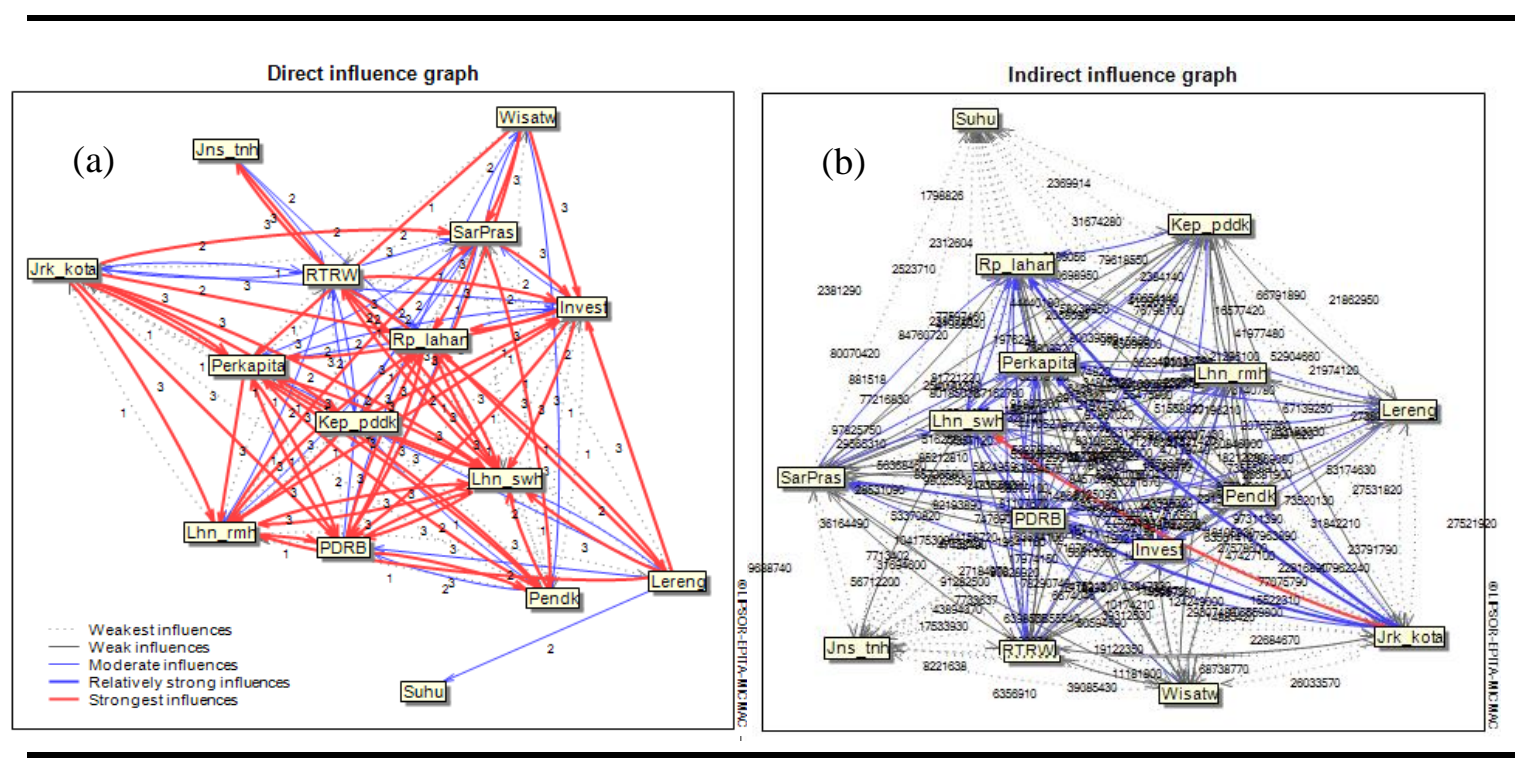

\section{Gambar 4. Hubungan Pengaruh Antar Variabel}

Berdasarkan Cross-Impact Matrix, dihasilkan hubungan antarvariabel dalam bentuk peta pengaruh. Gambar 4a menunjukkan hubungan pengaruh langsung antarvariabel terhadap perubahan penggunaan lahan menjadi lahan terbangun periode tahun 2002-2016. Semakin dekat jarak terhadap kota, maka semakin tinggi kepadatan penduduk di wilayah tersebut, sehingga menyebabkan keterbatasan lahan. Kebutuhan lahan akan perumahan/permukiman akan menyebabkan kompetisi penggunaan ruang, sehingga mengurangi luas lahan sawah. Di sisi lain, kebijakan RTRW yang diimplementasikan 
dengan baik akan menghasilkan iklim investasi yang dapat mendorong pertumbuhan ekonomi dan menjadi penunjang dalam mewujudkan pendidikan berkualitas sehingga dapat meningkatkan pendapatan perkapita masyarakat.

Hubungan pengaruh tidak langsung antarvariabel yang disajikan pada Gambar 4b, menunjukan hubungan yang kuat antara variabel jarak terhadap kota dengan proporsi luas lahan sawah. Semakin dekat jarak terhadap kota, maka proporsi luas lahan sawah akan semakin berkurang di masa depan. Hal ini ditandai dengan garis merah yang menghubungkan kedua variabel.

Tabel 5. Daftar Urutan Variabel-Variabel Berdasarkan Nilai Pengaruhnya

\begin{tabular}{|c|c|c|c|c|c|c|}
\hline Rank & Label & Direct influence & Label & Direct $d . .$. & Label & Indirect influence \\
\hline 1 & Jrk_kota & 1098 & Lhn_swh & 1333 & Jik_kota & 1099 \\
\hline 2 & RTRW & 823 & Rp_lahan & 1058 & RTRW & 807 \\
\hline 3 & Lereng _ & 823 & PDRB & $1058 \longrightarrow$ & Lhn_swh & 803 \\
\hline 4 & SarPras - & 784 & Invest & $1058 \longrightarrow$ & PDRB & 760 \\
\hline 5 & PDRB - & 784 & Rerkapita & 941 & Lhn_mh & 758 \\
\hline 6 & Lhn_swh & 784 & Lhn_mh & $901 \longrightarrow$ & SarPras & 758 \\
\hline 7 & Kep_pddK & 745 & SarPras & $784 \longrightarrow$ & Lereng & 758 \\
\hline
\end{tabular}

Kolom Direct Influence dan Indirect Influence hasil keluaran MICMAC pada Tabel 5 menunjukkan urutan variabel-variabel kunci berdasarkan nilai pengaruh langsung dan pengaruh tidak langsung. Jarak terhadap pusat kota, kebijakan RTRW, dan kelerengan merupakan variabel-variabel kunci yang berpengaruh pada periode tahun 2002-2016. Variabel-variabel jarak terhadap pusat kota, kebijakan RTRW, dan proporsi luas lahan sawah diprediksi akan berpengaruh terhadap perubahan penggunaan lahan menjadi lahan terbangun di wilayah Teluk Palabuhanratu di masa yang akan datang.

\section{Analisis Pengaruh Variabel-variabel Kunci Terhadap Perubahan Penggunaan Lahan Menjadi Lahan Terbangun}

Pada tahapan ini dilakukan analisis pengaruh variabel-variabel kunci terhadap perubahan penggunaan lahan menjadi lahan terbangun periode tahun 2002-2016 dan tahun 2016-2030 di wilayah Teluk Palabuhanratu.

\section{Variabel jarak terhadap pusat kota}

Perubahan penggunaan lahan menjadi lahan terbangun pada radius antara 0-5 Km, 5-10 Km, dan 10-15 Km terhadap pusat kota tersaji pada Gambar 5. Peningkatan perubahan luas penggunaan lahan terbangun semakin tinggi seiring dengan kedekatannya dengan pusat kota.

Tabel 6. Perubahan luas penggunaan lahan periode tahun 2002-2016 dan 2016-2030 berdasarkan radius tertentu

\begin{tabular}{lllllll}
\hline \multirow{2}{*}{ Penggunaan Lahan } & \multicolumn{2}{l}{ Perubahan Tahun 2002-2016 (Ha) } & \multicolumn{3}{l}{ Perubahan Tahun 2016-2030 (Ha) } \\
\cline { 2 - 7 } & $0-5 \mathrm{Km}$ & $5-10 \mathrm{Km}$ & $10-15 \mathrm{Km}$ & $0-5 \mathrm{Km}$ & $5-10 \mathrm{Km}$ & $10-15 \mathrm{Km}$ \\
\hline Hutan & $-63,12$ & $-184,84$ & $-136,67$ & $-53,49$ & $-159,85$ & 151,92 \\
Kebun Campuran & $-21,60$ & $-2,83$ & $-4,39$ & $-18,21$ & $-1,84$ & 9,06 \\
Lahan Terbangun & 110,49 & 14,19 & 10,71 & 102,28 & 78,80 & 49,62 \\
Pasir Pantai & $-7,78$ & $-4,32$ & $-2,24$ & $-5,69$ & - & 2,53 \\
Sawah & $-49,22$ & 10,81 & $-0,56$ & $-45,33$ & $-37,59$ & 25,76 \\
Lainnya & 31,23 & 167,00 & 133,15 & 18,98 & 119,80 & 138,66 \\
\hline
\end{tabular}




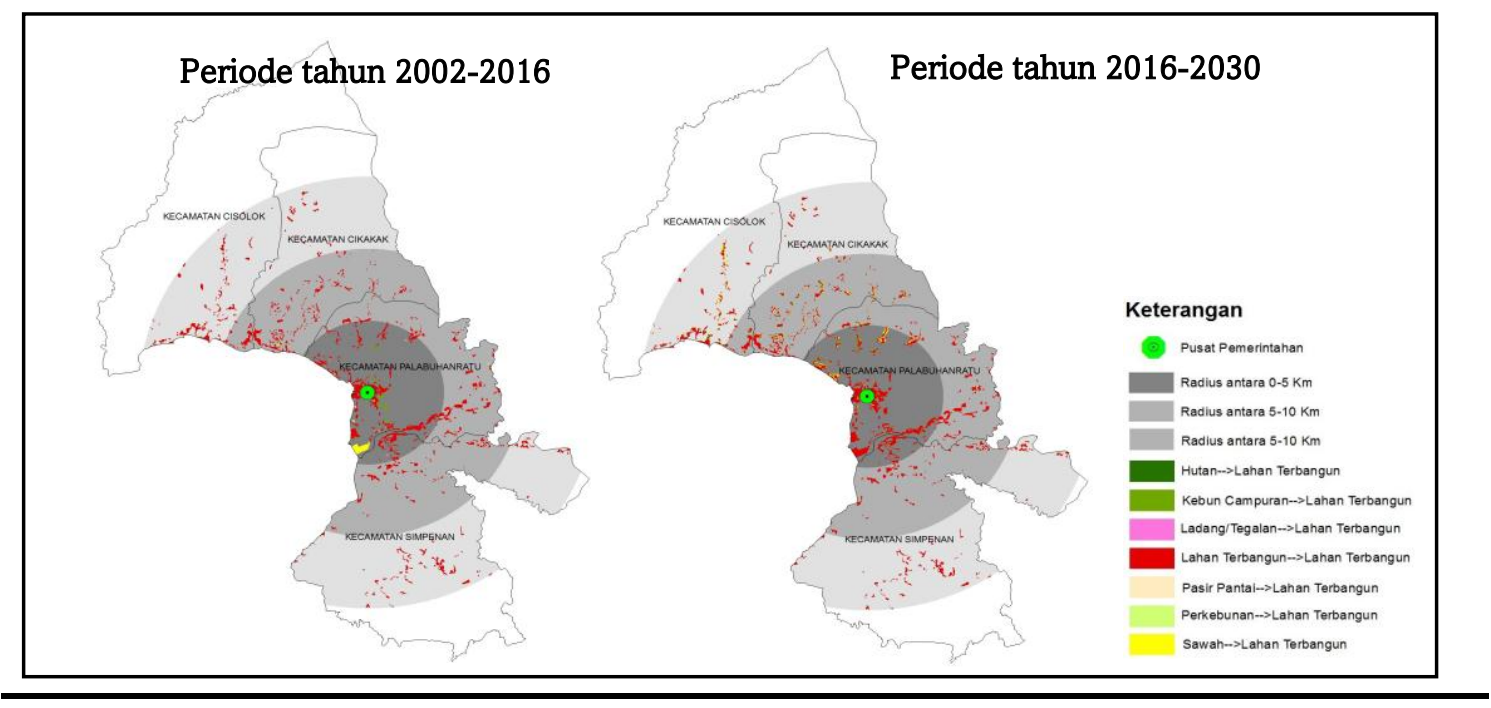

Gambar 5. Peta Pola Perubahan Lahan Menjadi Lahan Terbangun Radius Tertentu

Berdasarkan Tabel 6, baik pada periode tahun 2002-2016 maupun tahun 2016-2030, peningkatan luasan perubahan penggunaan lahan terbangun tertinggi berada pada radius antara 0-5 Km terhadap pusat kota, masing-masing sebesar 110,49 Ha dan 102,28 Ha. Penambahan luasan terbesar diperoleh dari penggunaan lahan sawah dan kebun campuran yang terjadi di Kecamatan Palabuhanratu. Perubahan luasan penggunaan lahan terbangun menurun seiring dengan semakin jauh jarak terhadap pusat kota.

\section{Variabel kebijakan RTRW}

Hasil analisis menunjukkan keselarasan pola penggunaan lahan menjadi lahan terbangun pada periode tahun 2002-2016 terhadap rencana pola ruang sebesar $74 \%$ $(102,20 \mathrm{Ha})$. Ketidakselarasan pola perubahan penggunaan lahan menjadi lahan terbangun sebesar 26\% (36,62 Ha) yang didominasi oleh pola perubahan penggunaan lahan kebun campuran menjadi lahan terbangun pada alokasi ruang pertanian lahan kering sebesar 6,40 Ha. Sebagian besar perubahan terjadi di Kecamatan Palabuhanratu.

Pengaruh kebijakan RTRW terhadap pola perubahan penggunaan lahan menjadi lahan terbangun pada periode tahun 2016-2030 dilakukan dengan mengimplementasikan kebijakan RTRW dengan asumsi bahwa perubahan penggunaan lahan menjadi lahan terbangun hanya diperkenankan pada alokasi ruang lahan terbangun. Hasil analisis menunjukkan keselarasan dengan rencana pola ruang yang telah ditetapkan di dalam dokumen RTRW sebesar 100\% (131,47 Ha) atau meningkat sebesar 28,18 Ha dibanding periode tahun sebelumnya.

\section{Variabel kelerangan}

Variabel kelerengan sering digunakan di dalam penentuan kawasan lindung, kawasan budidaya, maupun kawasan permukiman (Hidayati, 2013). Hasil analisis pada Tabel 7 menunjukkan pola perubahan lahan menjadi lahan terbangun yang semakin bertambah seiring dengan tingkat kelerengan lahan yang semakin rendah.

Peningkatan luasan penggunaan lahan terbangun terbesar berada pada tingkat kelerengan 0-5\% sebesar 70,10 Ha. Penambahan luas lahan terbangun terbesar diperoleh dari perubahan penggunaan sawah $(56,50 \mathrm{Ha})$, sebagian besar terjadi di Kecamatan Palabuhanratu $(55,47 \mathrm{Ha})$. Pola perubahan penggunaan lahan kebun campuran ke lahan terbangun sebagian besar terjadi pada tingkat kelerengan 5-15\%. Pola perubahan lahan ke lahan terbangun semakin rendah seiring dengan semakin tingginya tingkat kelerengan. 
Tabel 7. Pola Perubahan Penggunaan Lahan Berdasarkan Tingkat Kelerengan Lahan Periode Tahun 2002-2016

\begin{tabular}{|c|c|c|c|c|}
\hline \multirow[t]{2}{*}{ Pola Perubahan PL Tahun 2002-2016 } & \multicolumn{4}{|c|}{ Kelerengan (Ha) } \\
\hline & $\begin{array}{l}0- \\
5 \\
\%\end{array}$ & $\begin{array}{l}5- \\
15 \%\end{array}$ & $\begin{array}{l}15 \\
40 \%\end{array}$ & $\begin{array}{l}> \\
40 \\
\%\end{array}$ \\
\hline Sawah-->Lahan Terbangun & 56,50 & 2,81 & 1,40 & - \\
\hline Kebun Campuran-->Lahan Terbangun & 7,46 & 33,40 & 18,69 & 0,90 \\
\hline Pasir Pantai-->Lahan Terbangun & 3,92 & 0,90 & - & - \\
\hline PL lainnya--->Lahan terbangun & 2,22 & 4,62 & 5,78 & 0,20 \\
\hline JUMLAH & 70,10 & 41,74 & 25,88 & 1,10 \\
\hline
\end{tabular}

\section{Variabel Proporsi Luas Lahan Sawah}

Penurunan luas lahan sawah mengakibatkan pengurangan ketersediaan lahan yang akan mempengaruhi mata pencaharian petani. Hal ini akan mengakibatkan pergeseran tenaga kerja dari sektor pertanian ke non pertanian terutama lahan terbangun. Pengaruh proporsi luas lahan sawah terhadap peningkatan perubahan luas lahan terbangun pada masa yang akan datang disajikan pada Tabel 8 .

Tabel 8. Pengaruh Proporsi Luas Lahan Sawah Terhadap Perubahan Penggunaan Lahan Sawah Ke Lahan Terbangun Periode Tahun 2016-2030

\begin{tabular}{|c|c|c|c|c|}
\hline \multirow[t]{2}{*}{ Kecamatan } & \multicolumn{2}{|c|}{ Luas Lahan Sawah } & \multicolumn{2}{|c|}{$\begin{array}{l}\text { Pola Perubahan Lahan Sawah ke } \\
\text { Lahan Terbangun }\end{array}$} \\
\hline & $\mathrm{Ha}$ & $\%$ & $\mathrm{Ha}$ & $\%$ \\
\hline Simpenan & $1.385,91$ & 8,28 & 4,20 & 2,78 \\
\hline Palabuhanratu & $1.136,30$ & 12,30 & 63,16 & 41,72 \\
\hline Cikakak & $1.427,42$ & 12,63 & 45,45 & 30,02 \\
\hline Cisolok & $3.062,03$ & 17,62 & 38,56 & 25,48 \\
\hline JUMLAH & & & 151,37 & 100 \\
\hline
\end{tabular}

Semakin rendah proporsi luas lahan sawah terhadap luas wilayah, maka di masa yang akan datang diprediksi akan menyebabkan peningkatan perubahan luasan lahan terbangun di wilayah Teluk Palabuhanratu. Proporsi luas lahan sawah terendah berada di Kecamatan Simpenan dengan nilai 8,28\% (1.385,91 Ha), menyebabkan perubahan penggunaan lahan sawah menjadi lahan terbangun sebesar 4,20 Ha. Hal ini tidak sejalan dengan asumsi semula, diduga karena pengaruh dari kebijakan periode tahun sebelumnya yang mengarahkan Kecamatan Simpenan sebagai daerah yang diprioritaskan dalam pencetakan sawah baru, sehingga sawah yang ada saat ini ditetapkan sebagai sawah lindung yang tidak dapat dikonversi penggunaan lahannya.

Proporsi luas lahan sawah di Kecamatan Palabuhanratu sebesar 12,30\% (1.136,30 $\mathrm{Ha}$ ), menyebabkan perubahan penggunaan lahan sawah menjadi lahan terbangun sebesar 63,16 Ha. Hal ini diduga karena fungsi dari Kecamatan Palabuhanratu selain sebagai pusat pemerintahan dan ekonomi, juga ditetapkan sebagai pusat permukiman, sehingga di masa yang akan datang banyak dibangun prasarana dan sarana pendukung yang mengancam keberadaan lahan sawah. Semakin tinggi proporsi luas lahan sawah menyebabkan penurunan perubahan luasan lahan terbangun di wilayah Teluk Palabuhanratu.

\section{Arahan Pengendalian Pemanfaatan Ruang Lahan Terbangun di Wilayah Teluk Palabuhanratu}

Berdasarkan rangkaian hasil analisis yang telah dilakukan sebelumnya, dihasilkan arahan pengendalian pemanfaatan ruang lahan terbangun sebagai berikut. 


\section{Arahan pengandalian pemanfaatan ruang saat ini}

Pengendalian pemanfaatan ruang perlu dilakukan pada pemanfaatan ruang lahan terbangun yang menempati alokasi ruang lahan non terbangun pada radius $0-5 \mathrm{Km}$ terhadap pusat kota yang berada pada tingkat kelerengan 0-5\% dan 5-15\%. Kebijakan yang dapat dilakukan berupa kebijakan disinsentif berupa penyediaan infrastruktur secara terbatas dan sanksi administratif berupa pemulihan fungsi ruang dengan melakukan pembongkaran bangunan dan direlokasi ke tempat yang dialokasikan untuk lahan terbangun di sekitarnya.

Lahan pertanian yang telah terkonversi menjadi lahan terbangun dan lahan yang sudah merupakan lahan terbangun dialokasikan sebagai kawasan peruntukkan lahan permukiman/terbangun di dalam penyempurnaan RTRW selanjutnya.

Arahan pengendalian pemanfaatan ruang tahun 2016-2030

Pengendalian pemanfaatan ruang perlu dilakukan pada pola perubahan penggunaan lahan yang berpotensi menjadi lahan terbangun di daerah yang berada pada jarak radius 0$5 \mathrm{Km}$ terhadap pusat kota dengan proporsi luas lahan sawah terendah yang berada di luar alokasi rencana pola ruang. Jenis pengendalian pemanfaatan ruang yang diterapkan dapat berupa tindakan pencegahan melalui kebijakan insentif berupa perlindungan terhadap lahan pertanian yang diprediksi terkonversi menjadi lahan terbangun pada alokasi ruang lahan pertanian basah maupun lahan pertanian kering melalui program perlindungan pertanian pangan berkelanjutan berdasarkan UU No. 41 Tahun 2009

Penerapan peraturan zonasi diberlakukan terhadap permukiman petani pada alokasi lahan pertanian basah diarahkan pada permukiman kepadatan rendah. Pemberian ijin terhadap pendirian bangunan di lahan pasir pantai yang dialokasikan untuk lahan terbangun dibatasi hanya untuk menunjang kegiatan rekreasi pantai.

\section{KESIMPULAN}

Pada periode pasca perindahan ibukota kabupaten, perubahan penggunaan lahan terbangun mengalami peningkatan kenaikan luasan dibanding dengan periode pra perindahan ibukota kabupaten, sementara pasir pantai mengalami penurunan luasan perubahan penggunaan lahan yang cenderung terus meningkat. Hasil prediksi tahun 2030 menunjukkan penggunaan lahan pasir pantai dan tubuh air mengalami penurunan luasan terbesar lahan terbangun dan semak/belukar mengalami kenaikan.

Variabel jarak terhadap pusat kota, kebijakan RTRW, dan kelerengan merupakan variabel-variabel kunci yang berpengaruh terhadap perubahan penggunaan lahan menjadi lahan terbangun pada periode tahun 2002-2016. Sementara jarak terhadap pusat kota, kebijakan RTRW, dan proporsi luas sawah diprediksi akan menjadi variabel-variabel kunci yang berpengaruh pada periode tahun 2016-2030. Perubahan luasan penggunaan lahan menjadi lahan terbangun semakin tinggi seiring dengan kedekatannya dengan pusat kota dan cenderung mengarah ke wilayah dengan tingkat kelerengan 0-5\%. Kebijakan RTRW berpengaruh terhadap keselarasan perubahan penggunaan lahan menjadi lahan terbangun. Proporsi luas lahan sawah yang semakin rendah diprediksi akan menyebabkan peningkatan perubahan luasan penggunaan lahan sawah ke lahan terbangun.

Kebijakan disinsentif dan sanksi administratif diberlakukan terhadap lahan pasir pantai yang terkonversi menjadi lahan terbangun pada alokasi ruang sempadan pantai. Pendirian bangunan di lahan pasir pantai yang dialokasikan untuk lahan terbangun dibatasi hanya untuk menunjang kegiatan rekreasi pantai. Lahan terbangun dan lahan pertanian yang telah terkonversi menjadi lahan terbangun supaya dialokasikan pada kawasan peruntukkan lahan terbangun. Perlindungan terhadap lahan pertanian yang belum terkonversi menjadi lahan terbangun pada alokasi ruang lahan pertanian dilakukan melalui program perlindungan pertanian pangan berkelanjutan. 


\section{UCAPAN TERIMAKASIH}

Ucapan terima kasih disampaikan kepada Pusat Pembinaan dan Pendidikan Pelatihan Perencana (Pusbindiklatren)-BAPPENAS RI selaku pemberi dana beasiswa.

\section{DAFTAR PUSTAKA}

Albala MA, Lozano JMM, Hernandez PPP. 2009. Prospective Structural Analysis: An application to Rural Development Strategies. Confrence of the Agricultural Economics Society. Cordoba [ES]: University of Cordoba

Godet M, Durance P, Adam G. 2008. Strategic Foresight La Prospective Use and Misuse of Scenario Building. LIPSOR Working Paper. Paris [FR]: LIPSOR

Hidayat W, Rustiadi E, Kartodihardjo H. 2015. Dampak Pertambangan Terhadap Perubahan Penggunaan Lahan dan Kesesuaian Peruntukan Ruang (Studi Kasus Kabupaten Luwu Timur, Provinsi Sulawesi Selatan). Jurnal Perencanaan Wilayah dan Kota. 26(2): 130-146.

Hidayati IN. 2013. Pengaruh Ketinggian Dalam Analisis Kemasuk-Akalan Penggunaan Lahan (Plausibility Function Analysis of Elevation Effect for Optimizing Land Use Classification). Jurnal Globe. 15(1): 1-11.

Pemerintah Republik Indonesia. 1998. Peraturan Pemerintah Nomor 66 Tahun 1998 Tentang Pemindahan Ibukota Kabupaten Daerah Tingkat II Sukabumi Dari Wilayah Kotamadya Daerah Tingkat II Sukabumi Ke Kota Palabuhanratu di Wilayah Kecamatan Palabuhanratu. Jakarta [ID]: Sekretaris Kabinet RI

Jensen JR. 1996. Introductory Digital Image Processing: A Remote Sensing Perspective. 2nd Edition. New Jersey [US]: Pre1ntice Hall

Kim I, Jeong GY, Park JS, Tenhunen J. 2011. Predicted Land Use Change in the Soyang River Basin, South Korea. Terecco Science Confrence. October 2-7. Garmish-Pasrtenkirchen [DE]: Kasrlsruhe Institut of Technology. (1):17-24.

Muiz A. 2009. Analisis Perubahan Penggunaan Lahan di Kabupaten Sukabumi. [tesis] Program Studi: Ilmu Perencanaan Wilayah. Bogor [ID]: Insitut Pertanian Bogor.

Munibah K. 2008. Model Spasial Perubahan Penggunaan Lahan/Penutupan Lahan Dengan Pendekatan Cellular Automata: Studi Kasus Das Cidanau, Provinsi Banten. Jurnal Globe. 10(2): 108-120.

Nouri J, Gharagozlou A, Arjmandi R, Faryadi S, Adl M. 2014. Predicting Urban Land Use Changes Using a CAMarkov Model. Arabian Journal for Science and Engineering. 39(7): 5565-5573.

Septiono DS, Mussadun. 2016. Model Perubahan Penggunaan Lahan Untuk Mendukung Rencana Pengelolaan Kesatuan Pengelolaan Hutan (Studi Kasus KPH Yogyakarta). Jurnal Pembangunan Wilayah dan Kota. ;12 (3): 277-292.

Serrano MMD, Albala MA. 2010. Rural Development Drivers and Public Policy Formulation: The Use of Prospective Structural Analysis. Confrence of Euro pean Association of Agricultural Economist (EAAE). August 25-27. Cordoba [ES]: University of Cordoba.

Setiawan B, Rudiarto I. 2016. Kajian Perubahan Penggunaan Lahan Dan Struktur Ruang Kota Bima. Jurnal Pembangunan Wilayah dan Kota. 12(2): 154-168.

Susilo B. 2011. Permodelan Spasial Probabilistik Integrasi Markov Chain dan Cellular Automata Untuk Kajian Perubahan Penggunaan Lahan Skala Regional Di Provinsi Daerah Istimewa Yogyakarta. Jurnal Gea. 11 (2): 163-178.

Tobler W. 1987. Measuring Spatial Resolution. Proceeding, Land Resource Information System Confrence. Beijing. pp 12-16.

Trisasongko BH, Panuju DR, Iman LS, Anjani V, Harimurti, Ramly AF, Subroto H. 2009. Analisis Dinamika Konversi Lahan di Sekitar Jalur Tol Cikampek. Publikasi Teknis DATIN. Jakarta [ID]: Kementrian Negara Lingkungan Hidup.

Wahyudin Y. 2011. Karakteristik sumberdaya Pesisir dan Laut Kawasan Teluk Palabuhanratu, Kabupaten Sukabumi, Jawa Barat. Bonorowo Wetlands. 1(1): 19-32.

Wang SQ, Zheng XQ, Zang XB. 2012. Accuracy Assessments of Land Use Change Simulation Based on Markov-Cellular Automata Model. Procedia Environmental Sciences. ;13(2011): 1238-1245. 